\title{
THE USE OF FIGURATIVE LANGUAGE IN KATY PERRY SONG
}

\author{
Sri Arfani \\ Universitas Bina Sarana Informatika \\ Jl. Salemba Tengah No. 45. Jakarta Pusat \\ sri.saf@bsi.ac.id \\ Sri Chandra Damayanti \\ Universitas Bina Sarana Informatika \\ dhamaniasfamily@gmail.com
}

APA Citation: Arfani, S., Damayanti, S.C. (2019). The Use of Figurative Language in Katy Perry Song. Journal of English Language and literature, 4(2), 19-27. DOI 10.37110/jell.v4i02.76

Published:01-09-2019

\begin{abstract}
The objective of this research is to analyze slang words in Top Five movie. Learning slang is important for people who want to fully understand English either it is formal or informal. The movie is analyzed using the descriptive qualitative method. The data were collected through library and internet research then watch the movie several times. The first analysis of the research is about slang words that used in the movie. The second analysis is about forms of slang that found in the movie. Then the third analysis is about functions of slang words used in the movie. The result of this research indicated that: (1) There are ten slang words that are going to discuss in this research, (2) There are eleven forms of slang that found in the movie; compounding, affixation, phraseology, clipping, initialism, verbification, nominalization, other process, blending, (3) There are nine functions of slang that used in the movie; identification, interaction, secrecy, emotions, humor, toughness, informality, conciseness, and forcefulness.
\end{abstract}

Keywords: Slang, Forms of Slang, Functions of Slang, Top Five Movie.

\section{INTRODUCTION}

In this globalization era, many people want to learn English, to be able to speak English fluently, and to understand English correctly. As the international language, English is used everywhere, and almost all professions require the ability to speak English. The basic thing to learn English easier is to know a lot of vocabulary. The simple way to do it is through listening to the music, because not only know a lot of vocabulary but also know how to pronounce it.

Song lyrics are expressions that a person has a thing that he or she has seen, heard or experienced. Poet or songwriter expresses an experience by playing words and languages to created attraction and uniqueness of the lyrics or poems. Song lyrics also form from the language resulting from the communication between the songwriter and the people who loves the songs. And it also has its own peculiarities and features compared to the rhymes, because the pouring of ideas through song lyrics is reinforced by melodies and rhythm types adapted to the lyrics of the song. It is concluded that the song is a composite artwork between sound art and poetic language art. The language is short and there is a rhythm with a coherent sound, the election of figurative or imaginative words, involving the melody and the singing voice.

Figurative Language that in Indonesia called as Majas, is usually used to create certain effects. It is a rhetorical form that is shown to create an imaginative impression. It is a form of deviation from the language used. The 
deviation of meaning and also the deviation of the word order in order to gain a more specific meaning such as comparing or associating two things. There are many kinds of figurative language such as Metaphor, Simile, Personification, Hyperbole, and Symbolism. Figurative languages also include unusual constructs or word combinations that provide a new perspective, for example Onomatopoeia, Idiom, Synecdoche, Cliché, Assonance, and Metonymy.

Figurative language is difficult to understand because of its unique and its unpredictable meaning. Figurative language can bring difficulties in understanding ideas of the words. So, in this final assignment, the writer tries to discover the true meaning of words in kind of Figurative Language. So that, this study focuses on "The Used of Figurative

\section{Language in Katy Perry Song"}

Based on the background and reason of choosing the title above, the writer can identify those problems as follows:

1. What kind of figurative languages are used in song of Katy Perry selected song ?

2. What are the messages in song of Katy Perry selected song?

\section{THEORETICAL FRAMEWORK}

These reviews are expected to serve important background information to support the study and the discussion of the findings. It is divided into three subtopics: (a) Figurative language, (b) Meanings, (c) Song Lyric, (d) Message.

\section{a. Figurative Language}

Figurative languages are most often used in poetry, songs and are also often used in both fiction and nonfiction writing. It is also used when people talk, just think idioms. It means that figurative language is an expression used by person or the author indirectly by using the comparison. According to Kokemuller in Putri, et al, (2016: 119) said that: Figurative language plays a major role in compelling literary works. Figurative language is a contrast to literal language. Its primary purpose is to force readers to imagine or intuit what an author means with an expression or statement. Applying the right element in making specific points in writing is necessary to make figurative language work. Regardless the tool, figurative language strengthens or makes a point more compelling and effective.

It means that figurative language has its own role in literary works that can attract anyone, and the ultimate goal is to force anyone who reads the work to imagine what the author means by expression or by statement. It is also necessary to apply appropriate elements in making certain points for figurative language, as well as figurative language will create interesting and effective points in making literary works.

While Shen in Salwa \& Liskinasih, (2016) argues "Figurative language is language deflection to create certain and rhetorical effects or special meanings". It means that figurative language is used to create a certain effect that makes the work interesting and liked by many, and also has a meaning or rhetorical meaning which is used to influence others around it in a persuasive way.

Regarding to McKenzie in Nuraeni \& Peron, (2017: 123) States that "Figurative Language refers to language that communicates ideas beyond the literal meaning of word". It means figurative language makes writing concrete, and because language can adapt and is suitable for very imaginative use.

According to Arvius Alm in Hayani, et al, (2016: 132) There are ten kinds of figurative language used by the writer in this study:

\section{Metaphor}

Metaphor is kind of figurative language that made comparison between two things that different to identify one with another. Metaphors are used in songs or poems to describe the emotions, feelings, and relationships of other elements that cannot be explained in ordinary language. For example the phrase "His lips is a blooming rose" clearly does not literally mean what he says, it is a 
metaphor that makes the comparison between the red beauty and the promise of the rose that blooms with the lips of the woman depicted.

\section{Personification}

Personification consists of giving human characteristics to an object. Personification is a figure of speech that describes something that is not human as though it could feel, think, act, live, or die in the same way as people. For example "I see the moon follow me wherever I go".

\section{Hyperbole}

Hyperbole is the term used that overstatement. This figure use by someone who has desire and expectation to the thing that happen to make object more greater than the real object. For example "It was cold, I saw polar bears wearing jackets".

\section{Simile}

Simile is the figure that make comparison between two different things, just like metaphor but in simile usually using the word as, than, like, seem, so, appear, more than. A simile example is to say "They fight like cats and dogs".

\section{Metonymy}

Metonymy is a word or complex expression that basically stands for one thing, or it also use for one lexical thing which connected with other through experience. Example "The White House claims that they welcome Syrian refugee". Meaning that "The White House" above refers to the government of the United States.

\section{Synecdoche}

Synecdoche is a figure of speech that a part refers the to specify whole. Synecdoche which expresses either more or less than it literary denotes. For example, "The captain commands one hundred sails" is a synecdoche that uses "Sails" to refer to ships into ships being the thing of which a sail is a part.

6. Irony
Irony statement are untrue, based reasoning that interpreted by the hearer from the speaker"s meaning, if irony not praise but usually criticism. Example: "The audience knows the killer is hiding in a closet in a scary movie but the actors do not."

\section{Antithesis}

Antithesis is figure speech that combine two things which different or contradiction in one sentence or negation. Antithesis is a device for placing opposing ideas in grammatical parallel. Antithesis is results when a pair or more strongly contrasting terms are presented. Example:"Guarantees to enter heaven are not based on being poor or rich."

\section{Symbolism}

Symbolism is a kind of figure speech that using symbol of animal, plants, or things for substitute something. Symbolism established from the result of personal; experience or fantasies. For example "Pretend to apologize as well as a chameleon looking for a gap for camouflage."

\section{Paradox}

Paradox is a figure speech that deliver two things which contradictory but this figure reveal the real fact that make sense even the speaker or the writer use a word that absurd. Example "Tension causes everyone in this air conditioned room to overheat."

It means that figurative Language also has various types. Some of them are metaphors, personification, hyperbole, simile, metonymy, synecdoche, irony, antithesis, symbolism and paradox. Of course it all depends on how to use it.

Based on the definitions above it is assumed that figurative language relates to a language that uses figurative and language cannot be taken only literary and is used to express the writer inner feelings. also have a meaning or that is rhetorical. With the ultimate goal is to force anyone who reads the work to imagine what the author intended by expression or statement. 
b. Song Lyric

Lyrics or poems are part of the song and message the songwriter wants to convey, and the lyrics can also be categorized into literary arts because that is including poetry.

According to Kennedy and Gioia in Diniari \& Fahrudin, (2015: 4) "Words combined with music have an effect unlike words without music or other instruments.'It means a word that when combined with music will have an effect that is different from words without music or other instruments).

Wile Mori \& Iwanaga in Nunes, et al, (2015: 188) argues "The majority of music that people listen to in their daily lives includes lyrics, and this is especially true for popular music." It means the lyrics and music can not be separated from everybody's life, as well as for popular music that requires lyrics.

The writer concludes that all theorists or poetry theories are part of the song and message the songwriter wants to convey, and the lyrics can also be categorized into literary arts because it is poetry. Because in expressing the experience, the poet or songwriter performs words and languages to create attraction and uniqueness in the lyrics or poetry. It is not only include the literary types but also the proverbial expressions, advertising messages, political slogans, pop song poems and prayers.

\section{c. Meaning}

Meaning is an inseparable part of semantics and is always inherent from anything that people say. Understanding its own meaning is very diverse and it can be said that the definition of the meaning is very difficult to determine because each language user has the ability and perspective that differ in interpreting a speech or word.

According to Wijana in Kustriyono, (2016: 15) Stated that "Linguistic forms, such as morphemes, words, phrases, clauses, sentences, paragraphs, and discourses have a basis in the form of mental concepts in the human mind called meaning or sense." It means meaning will arise or be present when someone speaks a particular word, can imagine what is meant of the word and can explain its meaning).

Regarding to Larson in Trimastuti, (2017: 66) Stated that meaning can be classified into four. There are as follow:

1. Grammatical meaning. It has two definitions involving the meaning expressed by grammatical ending, word order or intonation on the part of meaning which varies from one from of paradigms to the other.

2. Lexical meaning is the meaning that is given by dictionary.

3. Textual meaning is the meaning that is acquired from the relationship among one word to another word in a sentence.

4. Contextual or situational meaning that arises from the situation or context where the words, phrase, sentence and expression are used.

In short, the meaning in semantics learns about how language can organize and also express a meaning. Which means the meaning will appear or present when someone speaks a certain word, can imagine what the meaning of the word and can explain its meaning. It can also distinguish between meanings such as grammatical meaning, lexical meaning, textual meanings, and meaningful contextual meanings such as contextual meaning is the meaning that arises from the situation or context in which the words, phrases, sentences and expressions are used.

\section{d. Message}

Message are any words or communications, both oral and written that are sent from one person to another. Messages are at the core of every communication process that exists. In general, the message type is divided into two, verbal and nonverbal messages. When someone hears the word of communication then that is in the mind of the person is the writing, sound or picture that contains the message.

According to Redi Panujuin Sutika, (2014: 21) stated that That is hand gestures, 
head movement, posture and foot position, face expressions, face gaze, touch, parabahasa, physical appearance, smells, orientation space and personal distance." It means that hand movements such as used by a teacher in teaching time, including nods and also shake head teacher, posture and foot position can be used to show the emotions and also the attitude of the teacher.

Regarding to Devitoin Ramadanty, (2014:2) argues that Verbal communication is a communication that is oral or communication by using oral and written. It means through words, expressing feelings, emotions, ideas, conveying facts, data, and information and explaining it, exchanging feelings and thoughts).

In conclusion, message is any word or communication, whether oral or written, sent from one person to another. The general type of message is divided into two that is verbal and nonverbal messages. Communication can be either verbal or non verbal although two forms of communication are different but in practice complement each other. Like using hand gestures, head movement, posture and foot position, face expressions, face gaze, touch, parabahasa, physical appearance, and others are part of the nonverbal message. While writing or spoken is part of the verbal message.

\section{RESEARCH METHOD}

\section{Data source}

The data of this study were taken from music and reading the lyric on Katy Perry selected song.This song was choosen because it is one of the famous song in the world. It was chosen

\section{DISCUTION AND RESULT}

The writer analyzed the song of Katy Perry selected song. It was conducted to find out the figurative language used in that songs. The because there were so many figuratif words in this song that were very difficult to understand. So, it is interesting to identify the figuratif meanings and the messages on Katy Perry selected song.Method and technique of colleting data

This study used documentation method and technique of collecting data was done in some steps: the reseacher was listening to music and reading the lyric. Then the researcher attempts to find the words, phrases, and sentences which contain figurative language and also grasps the meaning of each figurative language. After collecting the data, the writer analyzes the data by classifying the kind of figurative language especially simile, metaphor, onomatopoeia, idiom, alliteration, hyperbole appearing in the song of Katy Perry selected song. Then the writer describes general meanings and the messages on Katy Perry selected song. Finally, the writer classifies data and rechecks it for making conclusions.

2. Method and technique of anaysing data

This study used the qualitative method and the data analyzed through steps: cheking the whole data that were collected in urban figuratif dictionary and Merriam Webster online dictionary whether they were figuratif words or not, identifying the figuratif types based on the theory of types of figuratif by Widawski (2015). Then, classifying the words formations used to create figuratif using the teory of word formations and the function proposed by widawski (2015), By using the theory about figurative language, each data is explained thoroughly. Finaly. drawing the conclusion based on the data of analysis.

figurative language used in that song can be seen in the table below.

\section{The Analysis Kind of Figurative Language in Katy Perry Selected Song.}




\section{a. Roar Song}

Table 1: Data Analysis of the Roar Song

\begin{tabular}{|c|l|c|}
\hline No & \multicolumn{1}{|c|}{ Expression/Lyric } & Figurative Language \\
\hline 1 & Louder, louder than a lion & Alliteration \\
\hline 2 & I let you push me past the breaking point & Hyperbole \\
\hline 3 & Dancing through the fire & Idiom \\
\hline 4 & $\begin{array}{l}\text { I used to bite my tongue and hold my } \\
\text { breath }\end{array}$ & Idiom \\
\hline 5 & I got the eye of the tiger, a fighter & Idiom \\
\hline 6 & Scared to rock the boat and make a mess & Idiom \\
\hline 7 & I went from zero, to my own hero & Metaphor \\
\hline 8 & Like thunder gonna shake the ground & Simile \\
\hline 9 & Now I'm floating like a butterfly & Simile \\
\hline 10 & Stinging like a bee I earned my stripes & Onomatopoeia \\
\hline 11 & You're gonna hear me roar! &
\end{tabular}

The table above explained the classification of figurative language used in the Roar song. It told in which position the figurative language occur in that song. The figurative languages which were found are: 1 alliteration, 4 idioms, 1 metaphor, 3 similes, 1 onomatopoeia. They are applied in that song as the messages of the text in roar song in order to create a beautiful meaning and creative literature, so the reader will be interested to listen to the song.

The following below are the explanations kind of figurative language in the Roar song :

1. Alliteration

"Louder, louder than a lion"

This is alliteration because it uses the letter "L" in repetitive sequence, and someone tries to say that it can make a loud noise that can be heard by others.

2. Hyperbole

"I let you push me past the breaking point"

This is hyperbole because it exaggerates that the person becomes frustrated and means that this person is too nervous to stand up for all the circumstances.

3. Idiom

"Dancing through the fire"

This is an idiom because the person really cannot dance with the fire and will get hurt. This means that the person will stand upright and succeed despite the pain.

"I used to bite my tongue and hold my breath" This is an idiom because it will not really bite the tongue nor does it hold its breath. Because if the person bites the tongue it will hurt the person and that person may faint from lack of oxygen. It means that the person is waiting for something bad to happen to that person.

"I got the eye of the tiger, a fighter"

It is an idiom because the person does not really have tiger eyes. By this means, that person is focused on the self and the future of that person also not on others.

"Scared to rock the boat and make a mess"

This is an idiom because the person can not really shake up a boat that will make a mess. What this means is that the person does not want to interfere with any situations and gets into trouble with what the person is doing.

4. Metaphor

"I went from zero, to my own hero"

It is a metaphor for comparing two things without using as or like. Zero and hero are in a very different part of the power scale or the other. And it also does not use words like or as. It shows how the person begins as a weak person and ends up as a very confident person. 5. Similes

"Like thunder gonna shake the ground"

This is a simile because the person uses the word "Like" to compare the person with the power of thunder. That person will make sure that the person can be like a capable thunder that shakes the ground and that means the person can make a big change.

"Now I'm floating like a butterfly" 
This is a simile because the person uses the word "Like" to compare the person with a butterfly. That means the person can be free to do anything and not worry about the things that will make the person fall.

"Stinging like a bee I earned my stripes"

This is simile because it uses the word "Like" to compare the person with a bee. By this means that the person feels that the person is brave and can do the job as well as a bee.

\section{Onomatopoeia}

"You're gonna hear me roar!"

This is onomatopoeia which is a word that imitates sounds like the sound of an animal, such as a sound in the roar of this song. "Roar" is like a roaring lion, which means that the person has shown the roar to everyone and that the person can rise up from his failure.

Furthermore, after analyzing the songs of Katy Perry Roar song, the writer concluded that this song shows the person is very strong, and able to make big changes in life. This also explained that everyone is a fighter and a champion who dares to make a change in life to show others that someone from scratch can become someone who is recognized by others. The song also shows the desire to live filled with enormous challenges and obstacles, and becomes an impetus for anyone who wants to change things. Likewise this song inspires anyone who wants to do everything for a big change to get better.

\section{b. Messages in songs of Katy Perry selected song}

In this sub-chapter, the author will explain the messages contained in the lyrics of Katy Perry selected song. The message will provide an understanding of the purpose of the songs and each song has its own meaning for the song maker so that people who hear the song will understand.

\section{Roar Song}

This song has a message not to give up. Despite the fall, must still rise and spirits. No matter what others say, even though their words just want to make others fall and feel unappreciated also want to give up. This song also invites everyone to not be afraid of anything, as an impulse, a call to stay strong.
It also inspires all those who want to survive, to encourage anyone who wants to become a champion or a person who is appreciated so that people who intend to underestimate or drop can see the sincerity that is in the person who is underestimated. An unappreciated person must remain confident in his or her own ability and must remain strong no matter what happens later. Still have to be firm on the stand and never give up. If the under privileged person gives up, then the underestimating person will feel happy because he has succeeded in dropping the spirit and hope of the person who is underestimated.

The song itself describes that loving person does not need any conditions. Even any shortcomings that exist in that person will be something more valuable. All bad and good things will be accepted without fears that will be a barrier in loving that person. No matter the difference of religion, race, physical, property or anything else, because love is actually blind, but not in terms of choosing and determining something better. It is being free and sincere in choosing something. People in love with wholeheartedly do not need to apologize for the shortcomings, because the person who loves nothing at all about it. In fact, it will do anything for that person, even though the storm and darkness are in front but it will go through for the sake of love. And the key of love is being able to accept all the shortcomings of the person who beloved.

\section{CONCLUSION}

After analyses and discussion have been discussed in chapter previously, so the conclusion will be discussed in this parts.

a. The Kind of Figurative Language in Songs of Katy Perry Selected Song

There are 10 kinds of figurative languages used in Katy Perry selected song : The figurative languages which were found are: 1 alliteration, 4 idioms, 1 metaphor, 3 similes, 1 onomatopoeia.. Based on the figurative languages in the lyrics of Katy Perry selected 
song, the researcher concluded that the most commonly found figurative languages are Similes, Repetitions, and Idioms. While the least figurative language found are Metaphors, Symbols, Alliteration, Metonymy, and Onomatopoeia.

b.The Messages in Song of Katy Perry Selected Song

The messages in the song of Katy Perry roar song describe that the song gives the spirit to not easily give up on anything even to people who intends to drop our hopes and spirits and just looks in one eye. This song also gives encouragement to anyone who wants to fight for life and show to anyone who underestimated him or her. In fact, people who is underestimated, could be better and than people who judges him or her, and may get more appreciation from others. For the second song

\section{REFERENCES}

Diniari, D., \& Fahrudin, D. (2015). Analisis Gaya Bahasa Dan Makna Pada Lirik Lagu Muse Dalam Album Black Holes And Revelations. Sastra Inggris, Fakultas Ilmu Pengetahuan Budaya, Universitas Indonesia, Kampus Universitas Indonesia, Depok, 1-12. Retrieved from http://lib.ui.ac.id/naskahringkas/201509/S44884-Dania Diniari

Djawad, A. A. (2016). Pesan, Tanda, dan Makna dalam Studi Komunikasi. ISSN 2527-4104, 1(1), 95-101. Retrieved from

http://jurnal.stkipbjm.ac.id/index.php/in do/article/download/75/60

Fitri, S. (2017). Analisa Semiotik Makna Motivasi Lirik Lagu " Cerita Tentang Gunung Dan Laut " Karya Payung Teduh. Jurnal Komunikasi, VIII(September), 256-261. Retrieved from

https://ejournal.bsi.ac.id/ejurnal/index.p $\mathrm{hp} / \mathrm{jkom} /$ article/download/3071/1955 of dark horse, this song has a message which is not to play with someone's love. Because Karma can happen to anyone who plays with someone's love. If a person hurts someone's heart, it will be rewarded with the same deed with what he or she does and vice versa. And in the last song is unconditionally song. This song has a message that love is unconditional thing. It does not look at someone from race, religion, national differences, and others.

Song of Katy Perry's selected song try to tell everyone about the human social life that contains about loves, sad, happiness, spirit, and others. In songs of Katy Perry selected song that contains figurative language is very helpful in understanding the song. The existence of figurative language complicates the understanding of the lyrics but to facilitate the understanding of the lyrics also gives effect to the song to make it more interesting.

Hayani, R. (2016). Figurative Language on Maya Angelou Selected. Widya Gama Mahakam Samarinda University, 1(2), 131-143. Retrieved from https://jurnal.fkipuwgm.ac.id/index.php/Script/article/vie $\mathrm{w} / 30$

Kustriyono, E. (2016). Perubahan Makna dan Fakta Penyebab Perubahan Makna Dalam Media Cetak (Kajian Semantik Jurnalistik ). Pendidikan Bahasa Dan Sastra Indonesia Universitas Pekalongan. Retrieved from http://journal.uad.ac.id/index.php/BAH ASTRA/article/view/4858

Makin, Z. F. (2014). Short Expression Di SMP Ali Maksum Bilingual language Jogja. ISSN: 2089-3884, 3(2), 173-185. Retrieved from https://linguistikademia.files.wordpress. com/2014/10/02-zahrul-edit1.pdf

Nunes, J. C., Ordanini, A., \& Valsesia, F. (2015). The power of repetition: Repetitive lyrics in a song increase processing fluency and drive market success. Journal of Consumer Psychology, 25(2), 187-199. https://doi.org/10.1016/j.jcps.2014.12.0 04 
Nuraeni, C., \& Peron, P. A. (2017). Figurative Language In Kelly Darrow' s Selected Poetry. Wanastra Vol IX No. 2 September 2017, IX(2), 122-129. Retrieved from http://ejournal.bsi.ac.id/ejurnal/index.ph p/wanastra/article/view/2480/1739

Putri, M. W., Oktoma, E., \& Nursyamsu, R. (2016). Figurative Language in English Stand-Up Comedy. English Review: Journal of English Education, 5(1), 89104. Retrieved from https://journal.uniku.ac.id/index.php/ER JEE

Ramadanty, S. (2014). Penggunaan Komunikasi Fatis Dalam Pengelolaan Hubungan Di Tempat Kerja. Jurnal Ilmu Komunikasi, Binus, 5 nomor 1, 1118. Retrieved from https://ejournal.unri.ac.id/index.php/JK MS/article/viewFile/2556/2511

\section{Biography}

Her name is Dr. Sri arfani, M.Pd. She was born on 25 Nofember 1973 in Bima west of Nusa Tenggara. She is an English lecturer of Communication and Language Faculty Bina Sarana Informatika University Jakarta. She started her career as English lecturer of UBSI
Salwa, S., \& Liskinasih, A. (2016). The Use of Songs in Increasing Students' Understanding of Figurative Language. IJEE (Indonesian Journal of English Education), 3(1), 76-88. https://doi.org/10.15408/ijee.v3i1.3443

Sutika, I. M. (2014). Mengelola Keterampilan Komunikasi Non Verbal Dalam Meningkatkan Motivasi Belajar Siswa. Jurnal Widya Acharya FKIP Universitas Dwijendra ISSN NO. 20850018, (2085), 26-35. Retrieved from http://ejournal.undwi.ac.id/index.php/wi dyaaccarya/article/view/22

Trimastuti, W. (2017). An Analysis Of Slang Words Used In Social Media. Jurnal Dimensi Pendidikan Dan Pembelajaran Politeknik Piksi Ganesha Bandung, 5(2), 64-68. Retrieved from http://journal.umpo.ac.id/index.php/dim ensi/article/download/497/509

in 2004 until now. She graduated from UNHAS Ujung Pandang in 1998, and continued her education to $\mathrm{S} 2$ degree in 2010 at UHAMKA Jakarta, then, continued her study in doctoral degree of UNJ in 2014 and graduated in 2017. She is available at sri.saf@bsi.ac.id 